Cornell Law Library

Scholarship@Cornell Law: A Digital Repository

Cornell Law Faculty Publications

9-2-2007

\title{
The Story of San Antonio Independent School Dist. v. Rodriguez: School Finance, Local Control, and Constitutional Limits
}

Michael Heise

Cornell Law School, michael-heise@lawschool.cornell.edu

Follow this and additional works at: http://scholarship.law.cornell.edu/lsrp_papers

Part of the Civil Rights and Discrimination Commons, Constitutional Law Commons, and the Education Law Commons

\section{Recommended Citation}

Heise, Michael, "The Story of San Antonio Independent School Dist. v. Rodriguez: School Finance, Local Control, and Constitutional Limits" (2007). Cornell Law Faculty Publications. Paper 76.

http://scholarship.law.cornell.edu/lsrp_papers/76 


\title{
CORNELL LAW SCHOOL
}

\section{LeGal Studies ReseArCh PAPER Series}

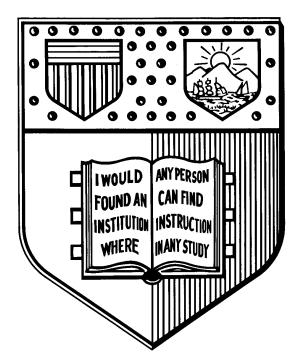

\section{The Story of San Antonio Independent School Dist. V. Rodriguez: School Finance, Local Control, and Constitutional Limits}

\section{Michael Heise}

\author{
Cornell Law School \\ Myron Taylor Hall \\ Ithaca, NY 14853-4901
}

Cornell Law School research paper No. 07-015

This paper can be downloaded without charge from:

The Social Science Research Network Electronic Paper Collection:

http://ssrn.com/abstract=1006743 


\title{
The Story of San Antonio Independent School Dist. v. Rodriguez: School Finance, Local Control, and Constitutional Limits
}

\author{
Michael Heise
}

\begin{abstract}
The story of San Antonio Independent School Dist. v. Rodriguez ${ }^{1}$ is comprised of many different stories deriving from many different perspectives. For Demetrio Rodriguez (and the other plaintiffs), the Rodriguez decision meant that the federal courts were not going to assist in a drive to secure greater school resources and increase equity among school districts in Texas. For the state of Texas (and, indeed, almost every other state), the decision prevented a dismantling of the basic architecture of the state's school finance system which relies heavily on local property taxes. As a consequence, per pupil spending in most states, including Texas, remains acutely sensitive to variations in local property tax receipts. For school finance reformers, the 5-4 defeat in Rodriguez precluded a single federal resolution to persisting school finance fights. To be sure, the Rodriguez decision did not end the school finance debate in Texas or elsewhere. Instead, the decision redirected reformers and their legal claims to state courts and constitutions across the country. For constitutionalists, the Rodriguez decision made clear (once again) that education is not a fundamental right, wealth is not a suspect classification, and the Constitution's reach has limits. So long as rationality tethers a state's school finance system to a legitimate end, Rodriguez insulates states from federal courts. Finally, for institutionalists, the Rodriguez litigation forced the Court to confront judicial capacity issues anew. Already humbled by the challenges incident to the federal courts' effort to dismantle de jure and de facto school segregation, the Rodriguez decision evidences reluctance by some of the Justices to become ensnarled in an effort to dismantle school finance systems in way that would affect an overwhelming majority of the nation's public schools. By side-stepping such a confrontation, Rodriguez implicitly reveals important aspects about the federal courts and, in particular, how the Justices view their role in our federal system and the Court's ability as an institution to achieve sought-after policy goals. These various stories and perspectives, separately and collectively, enrichen, fuel, and complicate Rodriguez's enduring and evolving legacy.
\end{abstract}

This Chapter seeks to convey the richness of the many stories and perspectives that collectively comprise Rodriguez. I first describe the major parties as well as the initial lawsuit in federal district court. I then turn to the judicial opinions generated by the district court and U.S. Supreme Court. A comparison of the two opinions reveals decidedly different approaches to such issues as judicial capacity, fundamental rights, and federalism. I also consider the opinions' practical consequences and place them into the broader legal context, especially with respect to the concurrent school desegregation 
litigation. I conclude with a brief review of the school finance setting in Texas today, including in the Edgewood and Alamo Heights districts, which illustrates that while Rodriguez may have answered some questions, it raised others and deflected school finance battles from the federal government to state governments.

\section{Demetrio Rodriguez and the Edgewood School District}

Demetrio Rodriguez, then six years old, moved in 1931 with his migrant farming family from a small Texas farming town near the Rio Grande to San Antonio in search of better public schools. In 1957, Demetrio, by then a U.S. Navy and Air Force veteran as well as a husband and father, moved his family to the Edgewood area, a "sprawling Hispanic barrio" on San Antonio's southwest side and close to an air force base where Demetrio worked as a sheet-metal welder. ${ }^{2}$

In 1968, public schools in the San Antonio area varied tremendously in numerous ways. The Edgewood school district, one of seven in the San Antonio area, enrolled approximately 22,000 students in its twenty-five elementary and secondary schools. ${ }^{3}$ Edgewood schools served predominately minority children (over 90 percent Hispanic and 6 percent African-American) from low-income households (\$4,686 median family income). ${ }^{4}$ The schooling situation was quite different in the nearby Alamo Heights school district, San Antonio's most affluent school district. Alamo Heights schools served students from wealthier households (median family income exceeded \$8,000) which were far more likely to be white (only 18 percent Hispanic and less than 1 percent African-American). ${ }^{5}$

Beyond potentially dry Census data on the two school districts, the Edgewood and Alamo Heights differed in other important ways. For example, parental education levels varied dramatically between the two districts. While in Alamo Heights 75 percent of the residents completed high school, fewer than one in ten of the Edgewood residents earned high school diplomas. ${ }^{6}$ These stark differences in education attainment levels correlated with other predictable differences, including employment outcomes. The Alamo Heights district teemed with lawyers, doctors, and bankers-professionals with college (and beyond) training. In 1970, for example, more than 50 percent of male workers in Alamo Heights held executive or professional titles. In Edgewood, however, only four percent of the males enjoyed similar success in the workforce. ${ }^{7}$

Although only a few miles separate the Alamo Heights and Edgewood school districts, from an educational perspective the two districts could not have been farther apart. Although it is seductively easy to become lost in the highly technical, arcane, and formulaic world of school finance, what typically lurks behind most discussions of mill levys, equalized tax rates, and assessed valuations is one profoundly simple yet forceful observation-education resources distribute unevenly across districts within a state. In 1968, the distribution of school resources in Texas followed a pattern typical for that era. Per pupil spending in Edgewood, an overwhelmingly poor and minority school district, was $\$ 356,{ }^{8}$ while per pupil spending in the predominately white and affluent neighboring Alamo Heights district was $\$ 594,{ }^{9}$ or two-thirds more. Although a per pupil spending 
difference of $\$ 238$ does not sound like much by today's school spending standards, in today’s (2006) dollars the difference amounts to $\$ 1,435$ per pupil. ${ }^{10}$

Making matters worse was that the per pupil spending disparity arose even though Edgewood residents taxed themselves at a rate higher than the Alamo Heights residents. ${ }^{11}$ To completely off-set the stark difference in property values between Edgewood and Alamo Heights and generate equal per pupil spending, the tax rate in Edgewood would have to have been be twenty times greater than the Alamo Heights tax rate. ${ }^{12}$ Adding further insult to injury was a Texas law that imposed a property tax ceiling which in effect precluded equal per pupil spending in Edgewood and Alamo Heights. Demetrio Rodriguez and other parents in the Edgewood school district confronted a vexing dilemma. Texas school finance law, specifically its reliance on local property tax revenues, generated considerable differences in per pupil spending and Texas tax law prevented equalization. Recognition of this dilemma, however, did little to ameliorate conditions in Demetrio Rodriguez's children’s dilapidated Edgewood schools.

\section{The Complaint}

About the same time Demetrio Rodriguz and other parents began focusing on school funding disparities with an eye toward possible litigation, two developments emerged. First, parents and activists in California were focusing in a similar-though distinct-way. One distinction in particular is critical. In their complaint in the Serrano litigation, the plaintiffs in California alleged state (as well as federal) constitutional violations in state court, ${ }^{13}$ claims that ultimately prevailed in the California Supreme Court. ${ }^{14}$ Second, emerging academic research (part of which stimulated and shaped the Serrano litigation in California) began to sketch the contours of a federal legal challenge to state school finance systems.

Frustrated with Texas lawmakers' disinterest in equalizing school spending, dispirited by their under-resourced schools, and buoyed by similar (though distinct) litigation in California, Rodriguez and other parents sought redress in the courts. Unlike their counterparts in California, however, Rodriguez turned to the federal constitution and federal courts. In 1968, with his children attending Edgewood schools, the forty-two year-old Demetrio (along with six other parents) filed a class action lawsuit in federal district court that fundamentally challenged the way Texas funded its public schools.

The complaint filed in Rodriguez is important for the arguments and theories it advanced as well as for those it did not. The lead attorney, Arthur Gochman, developed two principal claims. First, he asserted that low-income households, clustered in lowspending school districts like Edgewood, constituted a suspect class, thereby triggering strict judicial scrutiny of Texas' school finance system. Second, he argued that education was a fundamental right and, under the Fourteenth Amendment, Texas was obligated to provide it on an equal basis. Gouchman asserted that the per pupil spending disparities between Edgewood and Alamo Heights districts, as well as similar disparities between and among other school districts across Texas, evidenced unconstitutionally unequal treatment. 
Gochman's focus on poverty as a suspect classification warranting strict judicial scrutiny was not without legal precedent, albeit tangential to and non-binding in the education context. In Griffin v. Illinois, ${ }^{15}$ the United States Supreme Court struck down state laws that prevented an indigent criminal defendant from access to a trial transcript. The state fee requirements were held to discriminate against low-income defendants who were otherwise financially unable to access trail transcripts. Similarly, in Douglas v. California, ${ }^{16}$ the Court established an indigent defendant's right to court-appointed (and funded) counsel for those defendants with no other way to gain access to an attorney. Finally, in Bullock v. Carter, ${ }^{17}$ the Court invalidated a Texas filing-fee requirement for candidates seeking to compete in primary elections. Under the fee system, potential candidates without the financial ability to pay the filing fee were unable to compete for public office. The litigants in Rodriguez set out to leverage the comparative poverty in the Edgewood district and extend suspect class status-recognized by the Court in noneducation contexts - to include the school setting.

Although direct legal support for Gochman's argument that the per pupil spending gap between Edgewood and Alamo Heights students violated the federal Equal Protection clause was lacking, potentially analogous case law existed. One decision, Hobson v. Hanson ${ }^{18}$ involved per pupil spending variations within a single district-the District of Columbia public schools. Gochman sought to extend Hobson's logic to variation across districts within Texas. As well, the now-substantial intellectual and scholarly attention to school finance today ${ }^{19}$ was only emerging at the time Gochman crafted the Rodriguez complaint and, as a consequence, Gochman had comparatively fewer scholarly assets to leverage. ${ }^{20}$

Interestingly (especially so in the shadow of the concurrent school desegregation litigation), the Rodriguez complaint did not pursue racial (or ethnic) discrimination theories. Indeed, Gochman assiduously avoided casting the Rodriguez case as a "race" case. He ignored the racial and ethnic dimensions even though the Edgewood district was overwhelmingly Hispanic and the Alamo Heights district predominately white. Nevertheless, Rodriguez was consciously framed as a finance case and the attorneys in Rodriguez emphasized the Edgewood district's poverty rather than the district's overwhelmingly non-white citizenry.

What might explain the strategic decision to cast Rodriguez in financial rather than racial or ethnic terms? After all, racial discrimination was the dominant theme of the quickly maturing school desegregation jurisprudence. The absence of perfect correlation between ethnicity and geography might have deterred Gochman. (If so, his intuition was vindicated by the Court's reliance on a study by Professor Burke documenting something less than a perfect correlation between a school district's percentage of minority students and per pupil spending levels. ${ }^{21}$ ) Although Edgewood was overwhelmingly Hispanic, it was not exclusively so. Similarly, while Alamo Heights was predominately white, some-albeit few-residents were either Hispanic or nonwhite. Another possibility is that the predominately Hispanic Edgewood residents were simply more interested in increasing resources for their schools rather than increasing 
racial and ethnic integration levels. Regardless of the reason, it is difficult to overstate the strategic importance of the decision to frame Rodriguez in terms of poverty and education rather than in terms of race and ethnicity. ${ }^{22}$

By the time the district court decided the Rodriguez case the relevant legal terrain had evolved in important ways as the school finance litigation movement had begun in earnest. In Serrano v. Priest, ${ }^{23}$ the California Supreme Court concluded that within state per pupil spending variations violated the Fourteenth Amendment as well as state law. In Van Dusartz v. Hatfield, ${ }^{24}$ the court reached a similar conclusion and made the more subtle point that the wealth variations (specifically, the per pupil spending differences) were created by state policy. Although unavailable at the time Gochman crafted the legal complaint, the district court opinion in Rodriguez made good use of these new cases.

\section{District Court Decision}

Although the district court heard arguments in the Rodriguez case in 1968, its opinion was not issued until late 1971, more than three years after the lawsuit was filed. Because the case challenged state (Texas) law on federal grounds (Fourteenth Amendment), the case was argued to a three-judge district court panel. ${ }^{25}$ The district court panel initially wrestled with the standard of review question. The state of Texas urged the court to apply the less onerous rational basis test, while the plaintiffs urged strict scrutiny as the appropriate standard of judicial review. The district court concluded that because the Texas school finance system was based upon wealth-a suspect classification—and, in addition, implicated a fundamental interest — education—strict judicial scrutiny was warranted. ${ }^{26}$ To survive strict judicial scrutiny, the court noted that Texas must demonstrate that a compelling governmental interest supporting its use of a property tax-based school finance regime that generated uneven per pupil spending among districts across the state.

Texas' central argument, that its property tax-based school funding system enhanced local control and autonomy by giving local taxpayers a significant voice in deciding how much to spend on their local public schools, ${ }^{27}$ did not persuade the district court. Instead, the district court felt that Texas' school finance system, combined with state property tax caps, had the effect of reducing local district autonomy, ${ }^{28}$ thereby turning Texas' critical argument on its head. Because "Texas discriminates on the basis of wealth by permitting citizens of affluent districts to provide a higher quality education for their children, while paying lower taxes," the district court concluded the plaintiffs had been denied equal protection afforded by the Fourteenth Amendment. ${ }^{29}$

In addition to concluding that Texas failed to articulate and support a compelling governmental interest, the court went on to reach the far more provocative conclusion that Texas' school finance plan failed the far less onerous rational relation test. The federal district court felt that the purported relation between Texas' property tax-based school finance system was not rationally related to any legitimate governmental end such as local autonomy or control over local school spending. ${ }^{30}$ 
Setting aside formal legal reasoning, the palpable differences between the Edgewood and Alamo Heights schools likely were not lost on the three-judge panel hearing the case. One of the three, Judge Spears, appointed to the federal bench by President Kennedy, lived in Alamo Heights. According to one commentator, "[Judge] Spears knew very well the disparities between schools in Edgewood and Alamo Heights." ${ }^{31}$

Two key themes emerge from the district court opinion that continue to resonate throughout many aspects of education law in general and school finance litigation in particular. First, the court opinion implicitly equated "higher quality education" with higher per pupil spending. Second, the opinion conveyed some trepidation owing to separation of powers concerns.

\section{School Spending and Quality}

Embedded within the plaintiffs' complaint and the district court opinion is the assumption that the quality of education offered in Alamo Heights is superior to the education offered in Edgewood and that this quality difference is a function of per pupil spending. Such an assumption risks conflating education quality (and related reform efforts designed to enhance and more broadly distribute quality), school spending, and student academic achievement. ${ }^{32}$ By accepting such an assumption, the court presumed causal simplicity and clarity where reality is anything but simple and clear. If anything, debates over whether money "matters," especially as it relates to student academic achievement, are noted for their technical complexities and endurance. ${ }^{33}$ Explanations for and theories on why some students perform well and others perform poorly are endlessly debated in the literature. ${ }^{34}$

Two major studies, both by Professor Coleman, ${ }^{35}$ sparked public and academic debates about the relation between school spending and student achievement. In 1966, Coleman (and colleagues) released a large and controversial report on the nation's schools, which emphasized the influence of family and the socioeconomic status of a student's classmates on academic achievement. ${ }^{36}$ The study found that, from the perspective of influencing student academic achievement, school spending mattered very little and that a student's socioeconomic status mattered a great deal. ${ }^{37}$ Although the question about the relation between school spending and student academic achievement remains hotly contested ${ }^{38}$ the assertion that students' socioeconomic status matters a great deal has withstood the test of time. ${ }^{39}$ Numerous subsequent studies find that "the social composition of the student body is more highly related to achievement, independent of the student's own social background, than is any other school factor." ${ }^{40}$ Notably, education commentators of every political stripe acknowledge the robustness and consistency of these findings. ${ }^{41}$ Simply put, "[i]f there is one thing that is more related to a child's academic achievement than coming from a poor household, it is going to school with children from other poor households." ${ }^{42}$

In addition to exploring the larger question of whether money "matters" in terms of student achievement, scholars have compared results from schools that spend different 
amounts on similar types of students. Again, research by Professor Coleman resides at the heart of this ongoing debate. ${ }^{43}$ Professor Coleman (and colleagues) published the first major quantitative study exploring differences in student achievement between public and private (principally Catholic) schools and found that students in private schools performed slightly better, after controlling for student race and socioeconomic background. ${ }^{44}$ What makes the comparison especially important for the school finance debate in general and the Rodriguez case in particular is that many of the higher performing inner-city private schools spent less on a per pupil basis than their public school counterparts. ${ }^{45}$

\section{Separation of Powers and Judicial Remedies}

A second important theme developed in the district court opinion involves the court's sensitivity to separation of powers concerns. Mindful that it is not a "superlegislature, ${ }^{, 46}$ the district court's order evidenced some degree of tentativeness when it ordered relief that was prospective and became effective only if, after two years, the Texas Legislature did not modify the school finance system in a manner that addressed the court's concerns. ${ }^{47}$

What to make of the prospective relief awarded by the district court? Some view it as an abdication of the court's responsibility. ${ }^{48}$ After all, from a remedies' perspective the court effectively turned to the very institution that created the unconstitutional school finance system in the first place - the Texas General Assembly-for a resolution. Some wondered whether the court's approach to the remedy reflected a misapprehension of the lessons learned in Brown v. Board of Education (Brown II) ${ }^{49}$ and from the "with all deliberate speed" experiment. ${ }^{50}$ After all, one decade after Brown II, the Supreme Court itself remarked that the implementation of the desegregation remedy resulted in "entirely too much deliberation and not enough speed." ${ }^{51}$

The district court's prospective relief may also have reflected a necessary (if regrettable) judicial bow to reality. First, if the federal courts learned anything from the debate surrounding the "all deliberate speed" remedy articulated in Brown II they learned something about judicial capacity. In the school finance context, empirical evidence on the ability of court decisions to influence education spending is mixed, at best, and some suggest that courts in some states may have overestimated their comparative institutional strength. $^{52}$ Second, with something as technically complex as school finance, institutional capacity and comparative expertise suggest some role for state lawmakers and policymakers in fashioning a remedy.

Third, it is likely that political context cannot be ignored without peril. Indeed, Professor Gewirtz, ${ }^{53}$ among others, argues that "remedies must take account of resistance from the world they hope to transform and that in some cases courts may properly make compromises and limit remedies because of this resistance."54 Many governors and state lawmakers do not appreciate the perceived (or real) "end-run" around the legislative process to the courthouse in an effort to garner increased educational resources. Resistance to judicially-mandated or initiated school finance reform, both formal and 
informal, hinders many successful lawsuits that rely on legislators and governors for implementation at the remedial stage. Of course, such an argument risks collapsing into tautology. After all, one reason why successful school finance lawsuits, such as Rodriguez, may not generate the sought-after increased per pupil spending equity is precisely because courts may be reluctant to vigorously impose judicial sanctions owing to either real or theoretical separation of powers concerns.

The benefit of a two-year window to generate a legislative fix to the school finance problems the district court identified did not placate Texas lawmakers. Given the novel legal theories pushed in the Rodriguez complaint, Texas lawmakers were publicly (and privately) confident that the district court would see the situation their way and would not disrupt the Texas school finance system. Clearly, officials in Texas were caught off guard by the district court's decision. ${ }^{55}$ Not surprisingly, the defendants swiftly decided to appeal the ruling. Because of the case's unusual procedural posture, a direct appeal to the Supreme Court was possible and, indeed, successfully pursued by the defendants.

\section{Supreme Court Opinion}

The various parts of the Supreme Court's Rodriguez opinion consume 137 pages in the U. S. Reports and include concurring and dissenting opinions. Justice Powell, a Nixon appointee (and former Chair of the Richmond (Virginia) School Board), ${ }^{56}$ structured the opinion around three central tasks. First, the opinion distinguished the class of low-income members challenging Texas' school finance system from other lowincome individuals who successfully established poverty as a suspect class in other cases. ${ }^{57}$ Second, once establishing that the Edgewood schoolchildren did not constitute a suspect class, ${ }^{58}$ the Court concluded that public education was not a fundamental right under the U.S. Constitution. ${ }^{59}$ Third, without the benefit of a suspect class or a fundamental right, the Court left Rodriguez with only the argument that the Texas school finance system did not rationally relate to various state interests, including local control. The Court concluded that Texas' school finance system was not irrationally related to such legitimate governmental ends (such as local control), reversed the district court's holding, and upheld Texas’ school finance system.

The Court's decision had two immediate practical consequences for Demetrio Rodriguez in particular and the then-nascent school finance movement more generally. First, the opinion contributed significant momentum to the proposition that education was not a fundamental right under the federal constitution. During the second half of the twentieth century the Supreme Court had at least two separate and prime opportunities to deem education as a fundamental constitutional right. On both occasions, in Brown v. Board of Education (Brown I) ${ }^{60}$ and Rodriguez, the Court declined to make such a finding. In Rodriguez, the Court hinted at the hypothetical possibility of some federal constitutional right to education when it noted: "Even if it were conceded that some quantifiable quantum of education is a constitutionally protected prerequisite to the meaningful exercise of either right, we have no indication that the present levels of educational expenditures in Texas provide an education that falls short." ${ }^{61}$ While 
entertaining the possibility that the federal constitution might substantively require that Texas provide some level of education, the Court assiduously declined to articulate the federal threshold, save to remark that Texas already exceeded it. ${ }^{62}$

A second immediate consequence of the Rodriguez decision was to fundamentally redirect the school finance litigation movement. Although the decision shut the federal door on school finance litigation in federal court, the Rodriguez opinion did not end the school finance litigation movement. Instead, the decision redirected the litigation to state courts and state constitutions. Despite this abrupt change in fora as well as the source of a potential right, the school finance litigation movement survived the Rodriguez decision. Indeed, school finance activists did not have to wait long for success in the state courts. Just thirteen days following the Rodriguez decision, the New Jersey Supreme Court declared that its school finance system violated the New Jersey Constitution's promise for a "thorough and efficient education."63

\section{The Dissents}

Even if the Rodriguez was not a 5-4 decision, the dissenting opinions warrant careful consideration. The dissenting Justices pursued two main points. Justice White's dissent conceded rational relation as the appropriate standard for judicial review but (echoing the district court opinion) argued that the Texas school finance system nonetheless failed to meet the "rational" threshold. Justice Marshall's dissent, in contrast, argued that because education was a fundamental right the Texas school finance system warranted strict judicial scrutiny which, Marshall argued, it failed to survive.

Justice White, joined by Justices Douglas and Brennan, began his dissent by conceding the critical role played by local control and decision making in our democratic system of government. Nevertheless, Justice White went on to point out that to satisfy the rational relation test, the Texas school finance system must satisfy two elements. First, it must pursue a valid, rational, legislative end (enhancing local control). Second, the "means chosen by the State must also be rationally related to the end sought to be achieved."64

Justice White's dissent dwelled on the second element and construed the magnitude of the per pupil spending difference between the Edgewood and Alamo Heights districts as evidence that Texas' reliance on property-based tax revenues paradoxically undermined the state's articulated goal of enhancing local control. This paradox emerged because disparities in property valuations interacted with local taxing power incident to the Texas school funding system in a way that made it "impossible" for Edgewood residents to generate "comparable school revenues."65 And this impossibility, according to Justice White, makes Texas' school finance system constitutionally irrational because it turned Texas' purported rational for its desired legislative end-a school finance system that enhanced local control—on its head.

In contrast to Justice White, Justice Marshall continued to argue that education was a fundamental right. Justice Marshall's prior inability to persuade the Court to 
declare education as a fundamental right in Brown (as an advocate for the plaintiffs) did not deter him from revisiting the issue now that he sat on the Court. After categorizing Court pronouncements of education's importance, Justice Marshall developed the argument that education "directly affects" a child's ability to enjoy other core rights clearly articulated by the Constitution and deemed fundamental by the Court, such as speech. ${ }^{66}$ Justice Marshall argued that the nexus between education and the engagement in the political process was sufficiently robust that, according to Marshall, the former was fundamental as a matter of constitutional law and, as such, triggered strict judicial scrutiny of Texas' school finance system. Recognizing that some students in propertypoor schools academically out performed their counterparts attending property-rich schools ${ }^{67}$ helped prompt Marshall to shift his analytic focus of the Equal Protection Clause from student achievement (outputs) to education inputs (per pupil spending and taxing efforts). ${ }^{68}$

\section{Fundamental Rights and Limiting Principles}

In Brown, although the Court famously noted education's importance to citizens and society, ${ }^{69}$ the Court declined to construe education as a fundamental right. The plaintiffs in Rodriguez invited the Court to re-think the issue. Although the Court again concluded that education was important, ${ }^{70}$ it affirmatively and unambiguously declined to construe the right to education as fundamental. ${ }^{71}$ Indeed, one decade later in Plyler $v$. $D o e,{ }^{72}$ the Court reiterated this theme when it once again acknowledged that education, while not constitutionally fundamental, nonetheless occupied a "fundamental role in maintaining the fabric of our society.",73

Why has the Court for more than one-half century self-consciously declined to construe education as a fundamental right under the federal constitution? Or, more to the point, why did the Court in Rodriguez decline to extend the logic in Brown and deem education a fundamental right? For plaintiffs like Demetrio Rodriguez and, more importantly, his (and other) children attending Edgewood schools, the stakes were, of course, enormous. Were the Court to deem education fundamental, encroachments against education rights would trigger strict judicial scrutiny.

Ironically, some of the leading reasons offered to support education's status as a fundamental right help explain the Court's reluctance to embrace the argument. In Rodriguez, for example, the petitioners argued that education deserved elevated constitutional stature partly because of its nexus with other Court-recognized fundamental rights, notably those involving speech and voting. ${ }^{74}$ Such an argument is not without legal foundation. Prior to Rodriguez, the Court in Harper v. Virginia Board of Elections ${ }^{75}$ determined that a citizen's right to vote was fundamental because it is "preservative of other basic civil and political rights," ${ }^{, 76}$ such as political expression. ${ }^{77}$

From the Court's perspective in Rodriguez, however, such an argument proved too much and logically took the Court into uncomfortable terrain. The Court noted that such an argument lacked a limiting principle that would enable the Justices to clearly demark a boundary separating fundamental from non-fundamental interests. The Court 
wondered how one might distinguish education from hunger, clothing, or shelter in relation to the First Amendment or rights to meaningful political participation. And if a logically coherent line could not distinguish education from other such interests, the result would conflict with existing Court precedent (unchallenged by Rodriguez). ${ }^{78}$

That said, the Rodriguez Court conceded some analytic ground, if only rhetorically. Specifically, the Court held open the possibility that "some identifiable quantum of education" may, in fact, be fundamental as it might be required to protect other constitutional rights. ${ }^{79}$ Having raised the theoretical specter of education as a fundamental right, the Court then quickly dismissed the issue's relevance in Rodriguez by noting that whatever amount of education is required by the federal constitution, Texas met that minimal burden. Thus, the Court hinted at the conceptual possibility of a fundamental right in education without meaningfully defining that threshold, aside from a nod to Texas' efforts. ${ }^{80}$

\section{The Persistently Uneasy Relations Among Race, Resources, and Student Achievement in School Reform Litigation}

An important vein in the debate about the relation between school spending and educational opportunity involves the equally complex relation between school spending and race. The arguments advanced in Rodriguez, when combined with many arguments advanced in numerous school desegregation cases of that era, uncover a critical struggle to coherently synthesize the influences of race and resources on student academic achievement. The juxtaposition between the standard school desegregation case, moored in racial equality, and the nascent school finance cases, principally pivoting on economic disparity, could not have been more stark to the Justices on October 12, 1972, as on that day, both the Rodriguez and Keyes v. School District No. $1^{81}$ cases were argued.

In Keyes, the Court confronted the first major test of the de jure/de facto desegregation distinction. Two years earlier, in Swann v. Charlotte-Mecklenberg Board of Education, ${ }^{82}$ the Court articulated a rebuttable presumption of segregative intent where schools were "substantially disproportionate in their racial composition." 83 In Swann, the Court imputed the racially isolated schools to the district's prior de jure segregation policies. In Keyes, in contrast, Denver's school district never operated de jure school segregation policies. Nevertheless, due to complex interactions among such variables as population shifts, school district student assignment policies, and demographic trends, racially identifiable (and thus, under Keyes, presumptively unconstitutional) schools emerged. Embedded within school desegregation litigation efforts that sought to redistribute students within a district owing to race was an implicit assumption about disparities in school quality.

While Keyes understood equal educational opportunity (and thus, to some degree, school quality) in terms of race, Rodriguez, in contrast, eschewed that approach and instead operationalized educational opportunity in terms of school resources independent of race. Having embarked upon an argument that the low-income families in Edgewood were denied equal educational opportunity, the Rodriguez litigants claimed that, because 
of Texas' school finance system the Edgewood district was consigned to an inferior education (as compared to families in high-income districts). Although educational quality was operationalized largely in terms of traditional inputs - teacher turnover rates, teacher quality and experience, and school facilities-such outputs as student achievement and high school completion rates were also folded into the argument. ${ }^{84}$

Judicial remedies isolated problems flowing from competing conceptions of equal educational opportunity promoted in school desegregation and finance cases. As Professor Liu observes, ${ }^{85}$ while both Keyes and Rodriguez pushed the equal educational opportunity doctrine, the two cases differed in a critical assumption incident to the requested remedies. ${ }^{86}$ The Keyes litigation embodied an assumption that increased educational resources - absent integration-were ineffectual. The Rodriquez litigation, by contrast, implicitly assumed that increased educational resources were necessary to enhance equal educational opportunity even in intensely racially isolated schools. Unlike the district court's embrace of the asserted relation between school spending and quality, ${ }^{87}$ the Supreme Court's opinion conveyed discomfort with even entertaining what it characterized as a controversial assertion. ${ }^{88}$ No doubt owing to the complexity and uncertainty surrounding these issues, courts since Rodriguez remain split over their understanding of the relation between school funding and student achievement. ${ }^{89}$ Perhaps even more startling is the confidence expressed by some courts in reaching a firm conclusion on this issue, especially in light of the acknowledged uncertainty within the social science community. ${ }^{90}$

\section{Race, Resources, Rodriguez, and Hindsight}

Although the evolution of the equal educational opportunity doctrine includes a transition from a focus on race to a focus on resources and thereby cements a link between race and resources, ${ }^{91}$ the plaintiffs in Rodriguez took great pains to frame their lawsuit in terms of wealth disparity rather than race. This strategic decision was pursued despite palpable racial and ethnic dimensions that separate the Edgewood and Alamo Heights districts. Whatever the strategy's merits were in the late 1960s, conventional litigation wisdom today is to conflate-and not separate-school finance and race and ethnicity. $^{92}$

Efforts to separate wealth from race and ethnicity in the school context risk running against intellectual currents propelled by the Brown decision. While litigation aimed at eliminating school segregation on the basis of race descend directly from Brown, leading school finance litigants argue that school finance litigation resides within a "progressive legal dynamic" created by the Brown decision. ${ }^{93}$ Moreover, school finance and desegregation litigation persist as integral parts of a larger project seeking enhanced educational opportunity. ${ }^{94}$

Even if it made sense to divorce wealth from race and ethnicity in the school context during the late 1960s, as evidenced by Rodriguez's framing, from a practical standpoint it makes less strategic sense today. Indeed, the two litigation efforts complement each other. As Professor Ryan notes, ${ }^{95}$ it is easy to contemplate how school 
desegregation and finance litigation efforts could have coalesced in a way beneficial to poor and minority students by "ensuring that the fate of disadvantaged students was tied to the fate of their more advantaged peers." reform is far higher where its beneficiaries are not of one race, and desegregation is more palatable to more where all schools are already amply resourced. ${ }^{97}$ To some, then, the Sheff $v$. O'Neill ${ }^{98}$ litigation in Connecticut, which conspicuously conflated race and school finance, addressed a task side-stepped by the Supreme Court in Rodriguez: synthesizing school finance and desegregation theory in a manner that advances a broader understanding of equal educational opportunity. ${ }^{99}$

\section{The Lure of Local Control}

Presaging one key rationale supporting the outcome in Milliken v. Bradley, ${ }^{100}$ decided one year later, the Rodriguez opinion placed great analytic weight on the notion of local control and articulated fidelity to principles of federalism and separation of powers. The Court's comfort with local control in the education setting has increased over time. In Rodriguez, the Court concluded that local control was important and that Texas's reliance on local property taxes was not irrational. One year later (1974) in Milliken the Court more forcefully defended local control and declared: "No single tradition in public education is more deeply rooted than local control over the operation of schools; local autonomy has long been thought essential both to the maintenance of community concern and support for public schools and to the quality of the educational process."101 Indeed, the Milliken opinion cites to Rodriguez for support for the proposition that local control over education policy fuels citizen participation and education quality. ${ }^{102}$

A fidelity to local control over education policy continues to occupy an exalted place in American lore and exert significant sway over many citizens. ${ }^{103}$ Moreover, the education sector evidences a consistent desire to decentralize educational policymaking authority, especially as it relates to elementary and secondary education. In all states but Hawaii, for example, legislatures have delegated substantial policymaking authority to local school districts, governed by local school boards. ${ }^{104}$ The structural allocation of educational policymaking authority itself implies a belief that states and local school boards are comparatively better positioned to set desirable education policy and to do so in a manner that better reflects local conditions and preferences. ${ }^{105}$ Finally, key federal actors and institutions have long understood that education-particularly elementary and secondary education—resides at the core of state and local, not national, responsibility. ${ }^{106}$

The Court's fidelity to local control, however, rests increasingly uneasy in today's education setting. Stylized notions about local control over America's school policy, however powerful, have not accurately described the allocation of American education policy for decades. ${ }^{107}$ The influence of local school authorities on school policy has waned due to legislative assertions by states and the federal government. Thus, the Court displayed increased confidence in local control over school policymaking (including fiscal policy) as state and federal lawmakers encroached upon local autonomy. ${ }^{108}$ Since 
the 1970s the trend toward greater centralization of education policymaking authority has, if anything, accelerated and broadened.

State lawmakers started asserting greater policy control beginning the mid-1980s, as states assumed a greater absolute and relative share of local school funding responsibility. In some states the emergence of increased state control was in response to successful (or threatened or even unsuccessful) school finance litigation efforts. Also, governors, increasingly held politically responsible for school reform results, demanded greater policy control. Finally, in response to A Nation At Risk report in $1983^{109}$ and the explosion of legislative responses the report fueled, ${ }^{110}$ policymakers in many states began the task of reviewing and, in some instances, articulating for the first time goals for student education outcomes. All these factors inevitably led to a greater concentration of policy authority at the state level and a concurrent diminution of local control.

Ironically, state efforts to develop and implement standards and assessment regimes better enabled the federal government to enter the education policymaking field with greater force which had the practical effect of further blurring federalism lines and diluting local control. ${ }^{111}$ Federal involvement with K-12 education policy increased in dramatic fashion with the No Child Left Behind Act $2001^{112}$ ("NCLB”). At its core, NCLB leverages state-created standards and assessments, increases transparency by disseminating data on progress, and imposes consequences on local districts and schools for insufficient progress. States desiring NCLB funds must establish school accountability systems that moor annual student proficiency to math and reading assessments for grades three through eight. ${ }^{113}$ States must also gather, report, and disseminate results for all students as well as for various student subgroups that contain a minimum number of students. ${ }^{114}$ Although state standards must be "challenging,"115 NCLB essentially leaves it to the states to establish their own standards and assessments, as well as proficiency thresholds. ${ }^{116}$ A sliding scale of consequences befalls schools that do not achieve adequate yearly progress. ${ }^{117}$ In exchange for federal education dollars, districts and states must now submit to increasingly onerous federal education laws. One inevitable consequence of school reform initiatives at the state and federal levels (as well as increased state and federal education spending) has been a further dilution of local control over school policy.

\section{The Court As A “Super Legislature" and Practical Concerns}

Embedded within the Rodriguez opinion are logical dilemmas and practical concerns. For example, the Court points to federalism, fear of unintended consequences, and practical concerns as reasons for declining the plaintiffs' invitation to restructure much of the nation's school finance system. According to the Court, "consideration and initiation of fundamental [school finance] reforms" are issues properly "reserved for the legislative processes of the various States." "118 More specifically, proposed solutions to school finance problems "must come from the lawmakers and from the democratic pressures of those who elect them."119 By deferring to Texas lawmakers, the Court noted, "we [the Court] do no violence to the values of federalism and separation of 
powers by staying our hand.”120 The Court left unanswered, however, whether striking down the Texas law would also violate federalism principles. ${ }^{121}$

The Court noted its concerns about the possible consequences (unintended or intentional) and the potential political backlash that striking down Texas' school finance system might unleash. The concerns range from political resistance to calls for significant increases in education spending ${ }^{122}$ to exacerbating spending gaps between urban and suburban districts. ${ }^{123}$ Some-but not all-of the Court's concerns were wellfounded. The decades of judicial engagement with school finance reform since Rodriguez reveal that the Court's prediction about political resistance to calls for significant spending increases proved far more prescient than the Court's prediction about exacerbating gaps between urban and suburban districts.

Practical concerns also informed the Court's analysis in Rodriguez. At the institutional level, the opinion conveys a presumption of judicial incompetence, at least when it comes to the practical nuances of school finance. The opinion notes that "the Justices of this Court lack both the expertise and familiarity with local problems necessary to the making of wise decisions with respect to the raising and disposition of public revenues."124

Finally, the majority opinion in Rodriguez breaks with tradition by closing with a "cautionary postscript" ${ }^{\text {"25 }}$ that develops two general practical points. First, the Court characterizes Rodriguez's request as one that would involve billions of new tax dollars, ${ }^{126}$ "massive change," and "completely uprooting the existing (education) system.",27 Although noting that such predictions about the future consequences of upholding the district court ruling were little more than mere guesses, the Court clearly conveyed its unwillingness to risk such consequences. Having noted such "practical considerations," in an almost self-conscious gesture, the Court went on to explain that such considerations, "of course, play no role in the adjudication of the constitutional issues presented here."

Second, even though the Court concluded that Texas' school finance system passed constitutional muster, the Court also made clear its view that school finance reform was needed. ${ }^{129}$ The Rodriguez opinion specifically encouraged further attention from scholars. ${ }^{130}$ Despite suggesting that change was necessary, the Court's opinion closed on its most salient theme. That is, despite the necessity of reform, the Rodriguez opinion returned to a central theme that, as a matter of constitutional law, reform must flow from the legislature or executive rather than the judiciary. ${ }^{131}$

\section{The Influence of Student Research}

The Rodriguez lawsuit underscored student research's potential to influence litigation and judicial opinions. In 1965-three years before the Rodriguez complaint was filed-while pursuing a Ph.D. at the University of Chicago, Arthur Wise published an article that contemplated federal Equal Protection Clause dimensions flowing from per pupil funding disparities. ${ }^{132}$ Wise's full argument emerged two years later in his 
dissertation, ${ }^{133}$ which elicited a published response from one of his professors, ${ }^{134}$ and culminated in the 1968 publication of his influential book, Rich Schools, Poor Schools: The Promise of Equal Educational Opportunity. ${ }^{135}$

Elements of the Rodriguez complaint reveal the influence of Art Wise's work conducted while he was in graduate school. As early as 1965, Wise identified poverty's potential Fourteenth Amendment salience and argued that, from the perspective of school finance litigation, the criminal and education contexts were similar. ${ }^{136}$ The potential federal constitutional implications posed by intrastate variations in per pupil spending, such as what existed in Texas when Rodriguez was filed, were novel and a distinct break from Serrano's focus on the California constitution. By arguing that poverty constituted a suspect classification and triggered strict judicial scrutiny in the school setting, Wise articulated one of the Rodriguez lawsuit's two fundamental analytic pillars. ${ }^{137}$

Although graduate student work informed the structure of the Rodriguez lawsuit, law student research informed the Rodriguez opinion. ${ }^{138}$ One of the plaintiffs' central arguments was that low-income families clustered in the poorest property school districts and that Texas' school finance system discriminated against low-income students. That per pupil spending in the less affluent Edgewood schools was less than that in the more affluent Alamo Heights district evidenced the discrimination. The argument-critical to Rodriguez's case-necessarily assumed a relation between low-income households and low per pupil spending school districts, an assumption the district court accepted. ${ }^{139}$

A law student undertook a clever study which assessed whether poor families in fact clustered in the poorest property districts. The study analyzed data from the 130 largest towns in Connecticut, which accounted for 95 percent of the state population and 96 percent of the state's total property values. Although the author analyzed three separate-though related-premises critical to school finance litigation, the Court's Rodriguez opinion focused on the first premise: that individual wealth corresponded with [school] district wealth.

The law student considered three different ways to assess individual family wealth and six alternatives for school district wealth. Partial correlations analysis ${ }^{140}$ of the various combinations of family and school district wealth revealed several interesting outcomes. First, when poverty was construed to mean "percent of population living below the poverty line," no statistically significant correlation existed between families in poverty and total per pupil spending. ${ }^{141}$ Second, when district wealth was construed more narrowly and only in terms of residential property value, a statistically significant relation emerged between district wealth and family poverty. ${ }^{142}$ Third, ironically, when district wealth was defined in terms of business wealth, a positive correlation emerged with family poverty. That is, poor families tended to cluster in wealthier areas, where wealth was construed in terms of commercial and industrial property value. ${ }^{143}$ The authors noted that, at best, the statistical relation between families living in poverty and school district wealth was unclear. In terms of business and industrial wealth, however, low-income families were more likely to live in wealthier districts. Thus, the author 
concluded that "the popular belief that the 'poor' live in 'poor' [school] districts is clearly mistaken.”144

Although the study's methodology might be viewed as somewhat crude by today's standards, it was not at the time the work was published (1972). In terms of its probative value to the Rodriguez case, however, the study possessed important limitations. First, the study used cross-sectional (1970) data from one state (Connecticut). Whether findings from Connecticut could properly be generalized to Texas (or any other state) remained unclear. Indeed, the Court wondered whether the statistical findings in Connecticut "would be discovered in Texas."

What to do with such uncertainty, however, was a separate question. General scholarly norms, especially in the empirical social sciences, place the burden of such uncertainty on the shoulders of those seeking to expand the scope of research findings. Thus, professional prudence would counsel against social scientists drawing inferences for Texas from Connecticut's findings absent persuasive evidence that the two states were similar in salient respects. The Court (composed of jurists rather than formally trained social scientists), however, drew just such an inference. More specifically, because the plaintiffs in Rodriguez did not factually establish that poor families cluster in poor spending school districts in Texas, the Court implicitly assumed that the findings from the Connecticut study (finding no such clustering) were informative and, thus, rejected an assumption critical to the plaintiff's case in Rodriguez. ${ }^{146}$ In so doing, the Court effectively flipped the traditional social scientific burden placement.

\section{Rodriguez's Aftermath in San Antonio and Elsewhere}

To be sure, Demetrio Rodriguez (and others in the plaintiff class) lost in the United States Supreme Court. The loss all but foreclosed a single, national judicial solution to a persistent school finance dilemma. And losses in court, even 5-4 losses such as Rodriguez, resist sugar-coating efforts. Unlike many litigation losses, the outcome in Rodriguez was the end of one story and the beginning of many others, including protracted state court litigation and political squabbles in Texas. ${ }^{147}$ In 1991, reflecting on decades of school finance litigation and reform, then-Dean Mark Yudof predicted a "long and tedious" tussle between Texas courts and lawmakers and further observed that: "The story is beginning to resemble War and Peace, though it is likely to be less amusing. One can only hope that its conclusion will be less catastrophic.”"148 Although it is abundantly clear that the story in Texas is already long, it is far from clear whether anything resembling a conclusion is in sight more than three decades since the Rodriguez decision.

\section{Edgewood v. Kirby}

Just over one decade following the Rodriguez decision, another lawsuit was filed, this time in Texas state court. Unlike the initial lawsuit, in the state litigation the Mexican American Legal Defense and Education Fund (MALDEF) took the litigation lead and argued that Texas' school finance system violated the state's equal protection ${ }^{149}$ and education clauses. ${ }^{150}$ In 1989 the Texas Supreme Court sided with the school district 
and ordered state lawmakers to fix its school finance system in time for the 1990-91 school year. ${ }^{151}$ The 1989 decision unleashed a series of legislative efforts and successive litigation, culminating in Texas Senate Bill 7. ${ }^{152}$ Passed in 1993, Senate Bill 7 had the effect of reducing per pupil spending disparities by redistributing funds generated in wealthy districts to their less wealthy counterparts. ${ }^{153}$ A hold-harmless provision provides wealthy districts with some redistributive relief. Notwithstanding Senate Bill 7, funding disparities persisted and fueled subsequent litigation. Incident to litigation, the Texas Supreme Court concluded in 1995 (however reluctantly) that Texas' Senate Bill 7 passed constitutional muster. ${ }^{154}$

\section{Neeley v. West-Orange Cove Consolidated Schools}

School finance controversy in Texas did not end in 1995, however, with the final Edgewood litigation and the passage of Senate Bill 7. Senate Bill 7, which re-structured school finance, did so in a manner that created a state property tax, which is prohibited by the Texas Constitution. ${ }^{155}$ Indeed, the Texas Supreme Court noted as much and warned that Senate Bill 7, if ignored over time, would likely create additional legal problems sometime in the future. That future arrived in 2001 when Texas school districts initiated yet another round of litigation challenging the Texas school finance system for precisely the reasons the court warned of years earlier. ${ }^{156}$

The Texas courts' most recent activity will likely ensure even more litigation in the future, but, perhaps, on slightly narrower grounds. As expected, the Texas court concluded that the state's control over local taxation for education amounted to a de facto state property tax that violated the Texas Constitution. ${ }^{157}$ The 2005 court decision requires Texas lawmakers, once again, to take up the issue of school finance. ${ }^{158}$ If history is any guide, further litigation will arise regardless of what Texas lawmakers do.

The subsequent litigation, which will assuredly follow, will likely be somewhat more focused owing to the court's conclusion that Texas school finance system's deficiencies-including, notably, the substantial unequal access to education revenue-

do not render the school finance system constitutionally inadequate or inefficient. ${ }^{159}$ Given its historic prominence in the Texas school finance battles, it is not surprising that the Edgewood District, once again, led the charge on the inequitable claim. ${ }^{160}$ What is particularly ominous to Edgewood's prospects for litigation success in the future, however, was the Texas Supreme Court's finding that: "While the end-product of public education is related to the resources available for its use,... more money does not guarantee better schools or more educated students." ${ }^{161}$ Whether the Texas high court's recent decision in Neeley signals the Court's desire to wind down judicial engagement or, rather, merely a narrowing of the terrain in which the Court will engage remains to be seen. 


\section{The Twenty-First Century and an Emerging National Trend Toward Increased Judicial Reluctance}

The recent developments in Texas' multi-decade school finance litigation saga, ignited decades ago by Demetrio Rodriguez, are consistent with a potential nation-wide trend toward increased judicial modesty in the school finance setting. Specifically, courts have pulled back a bit in a few states where lawmakers and executives acted incident to litigation. ${ }^{162}$ Even where legislatures and executives acted in ways designed to address school finance challenges, follow-up litigation frequently ensues and asserts that constitutional violations persist. This follow-up litigation invites the judicial branch not only to re-engage with school finance policy but also to assume even broader and deeper roles in re-shaping school finance systems.

It is at this precise point where school finance litigation enters a critical stage. On the one hand, such litigation can follow the "New Jersey" path and risk a multi-decade struggle among the executive, legislative, and judicial branches over the school finance turf. ${ }^{163}$ On the other hand, recent experiences in others states differ and hint at a potential trend. During the 1990s state supreme court decisions in Alabama, Ohio, and Massachusetts were cited by school finance reform activists as evidence of a litigation strategy's efficaciousness. Subsequent decisions in all three states, however, suggest something of a judicial retreat. In 1993, an Alabama court boldly announced that the state was obligated to provide an adequate education to its citizens. ${ }^{164}$ The court order was especially particular in what it meant by an adequate education. ${ }^{165}$ More recently, however, the Alabama Supreme Court dismissed further proceedings, pointing to separation of powers concerns. ${ }^{166}$ Likewise, after protracted litigation in Ohio, in 2003 the Ohio Supreme Court terminated a trial court's jurisdiction over a school finance case and effectively brought to a close multi-decade litigation in Ohio. ${ }^{167}$

A similar court response emerged in Massachusetts. In 1993, Massachusetts' Supreme Judicial Court ruled in McDuffy $v$. Secretary of the Executive Office of Education $^{168}$ that the state failed to fulfill its state constitutional obligation and noted in particular the deleterious consequences of the state's overwhelming reliance on local property tax revenues. Three days after the McDuffy opinion was announced Massachusetts lawmakers passed the Education Reform Act of 1993 . $^{169}$ The Act radically restructured education in Massachusetts, especially as it related to school funding, student goals and performance, and school and school district accountability provisions. After another round of school finance litigation challenging the state's Education Reform Act, the Massachusetts high court concluded that the state had taken reasonable and appropriate steps in a timely manner to address school funding and student achievement disparities. ${ }^{170}$ The decision brought to a close twenty-seven years of litigation and twelve years of state court supervision over school finance matters in Massachusetts. $^{171}$

\section{Conclusion: Assessing Rodriquez’s Legacy}


Demetrio Rodriguez noted as recently as 2005 that the school finance fight he helped launch in 1968 is one that "you never get finished with."172 From Demetrio's perspective, while the struggle has yielded some progress, "the state doesn't really want to give every child in Texas a fair share of the state's wealth."173 Although emerging school finance litigation trends contribute to a broader understanding of Rodriguez and Demetrio's perspective, Rodriguez's full legacy is not yet understood, even though almost four decades have passed since the Rodriguez complaint was filed in federal district court.

On the one hand, the Rodriguez litigation may represent a mis-step that cost the Edgewood schools and residents six important years in terms of their quest for greater school finance justice. On the other hand-regardless of the loss at the U.S. Supreme Court-Rodriguez might be better understood as a necessary step. Once school finance reform activists learned that the U.S. Constitution would not construe education as a fundamental right or poverty as a suspect classification, the school finance movement understood precisely where it needed to fight its battles - in state courts and legislatures.

A responsible account of Rodriguez cannot run away from the decidedly mixed school finance litigation movement that Rodriguez both informed and helped inspire. Setting aside disputes about the efficacy of successful school finance lawsuits in generating sought after increases in educational spending, two large themes endure that almost crowd out technical academic debates. First, despite multiple decades of school finance litigation, it remains abundantly clear-indeed, painfully obvious - that far too many schools persistently fail their duty to competently educate. This is true in Texas as well as in every other state in the Union. Worse still, these failures remain hauntingly easy to predict. As Professor Howard Gardner ${ }^{174}$ notes:

Tell me the zip code of a child and I will predict her chances of college completion and probable income; add the elements of family support (parental, grandparental, ethnic and religious values) and few degrees of freedom remain, at least in our country. ${ }^{175}$

The notion that geography is educational destiny for children is precisely what Rodriguez endeavored to eradicate. To be sure, the plaintiffs consigned to the Edgewood district zip code lost in Rodriguez. But more than thirty years of Rodriguez-inspired school finance litigation has taken place, and plaintiff victories, while not assured, have increased over time. Despite such victories, however, the empirically demonstrable correlations Professor Gardner describes-correlations easily replicated by most secondyear graduate students-persist. And their persistence drives a stake through the heart of what Rodriguez sought to accomplish. Although reasonable observers may differ on how to best understand what equal educational opportunity means in any given context, reasonable observers should agree that if equal education means anything, at the very least, it must mean that geography should no longer predict a child's educational future. The link between the happenstance of geography and education quality is precisely what Rodriguez and the school finance litigation movement it contributed to sought to sever. Nevertheless, the link persists. It remains critical to understand why. 
The two zip codes at issue in Rodriguez-78237 and 78209-while close numerically remain far apart in terms of education futures. The former is the zip code for Edgewood schools; the latter for Alamo Heights schools. Although the magnitude of the gaps has lessened, differences in educational resources persist. Edgewood schools spend approximately $\$ 7,238$ per pupil and benefit from a 17:1 student-teacher ratio. ${ }^{176}$ For Alamo Heights schools, the figures are \$7,852 and 14:1, respectively. ${ }^{177}$ Setting aside nettlesome and complicated questions about causation, the Edgewood students continue to struggle despite decades of litigation. In 2004, 41 percent of Edgewood's tenthgraders and 71 percent of its third-graders passed various statewide standardized math and reading tests. ${ }^{178}$ Even though Edgewood students evidence progress, they still lag behind state averages (64 and 86 percent, respectively). As well, in 2003 Edgewood SAT takers averaged a combined score of 791 (out of 1600) compared with the state average of 989.

What to make of current data is far from clear. What is clear, however, is that Rodriguez's legacy remains mixed and it continues to mean different things to different people. Although the school finance reform movement-including its litigation pronghas long moved beyond the Rodriguez opinion, important challenges remain. While perhaps of little solace to Demetrio Rodriguez and the many children struggling to learn in Edgewood's comparatively under-resourced schools, the Supreme Court's deference to federalism in Rodriguez generated at least one unexpected result. By effectively closing federal courts to the school finance litigants in Rodriguez, the Court redirected the school finance reform movement to the nation's state legislatures, courts, and state constitutional text. In so doing, the school finance experience helped bring to life Justice William Brennan's plea for state supreme courts to continue the Warren Court's rights revolution under the auspices of state constitutional interpretation. ${ }^{179}$ Although the results have been mixed in the school finance context, school finance litigation serves as a powerful reminder to all about limits to the federal Constitution as well as the potential breadth, scope, and promise of state constitutions.

\footnotetext{
${ }^{1} 411$ U.S. 1 (1973).

${ }^{2}$ Peter Irons, The Courage of Their Convictions 283 (1988).

${ }^{3}$ Rodriguez, 411 U.S. at 11-12.

${ }^{4}$ Id. at 12 .

${ }^{5}$ Id. at $12-13$.

${ }^{6}$ Irons, supra note 2, at 286-87.

${ }^{7}$ Id. at 287.

${ }^{8}$ Id.

${ }^{9}$ Id.

${ }^{10}$ To convert 1967 to current (2006) dollars I used the Bureau of Labor Statistics inflation adjuster which is based on the Consumer Price Index. See Bureau of Labor Statistics Inflation Adjuster, at http://www.bls.gov/bls/inflation.htm (last visited June 5, 2006).

${ }^{11}$ Irons, supra note 2, at 287.
} 
${ }^{12} I d$.

${ }^{13}$ Serrano v. Priest, No. C 938254 (Super. Ct. Los Angeles County 1969), rev’d, 487 P.2d 1241 (Cal. 1971).

${ }^{14}$ Serrano v. Priest, 487 P.2d 1241 (Cal. 1971).

15351 U.S. 12 (1956).

16372 U.S. 353 (1963).

${ }^{17} 405$ U.S. 134 (1972).

18269 F.Supp. 401 (D.D.C. 1967), aff'd en banc sub. nom. Smuck v. Hobson, 408 F.2d 175 (D.C. Cir. 1969).

${ }^{19}$ Indicia of intellectual and scholarly attention to school finance and school finance litigation are wide and varied. They include significant law review symposium attention, e.g., Symposium: Investing in our Children's Future: School Finance Reform in the '90s, 28 Harvard Journal on Legislation (1991); peer-reviewed journals devoted to school finance scholarship, e.g., Educ. Fin. \& Pol'y, J. of Educ. Fin.; and an academic society, American Education Finance Association.

${ }^{20}$ See, e.g., John E. Coons et al., Private Wealth and Public Education (1970).

${ }^{21}$ See Rodriguez, 411 U.S. at 16 n.38.

22 See generally Goodwin Liu, The Parted Paths of School Desegregation and School Finance Litigation, 24 Law \& Ineq. 81 (2006) (discussing the strategic and conceptual issues flowing from the plaintiff's decision to push Rodriguez as a poverty rather than a race case).

${ }^{23} 487$ P.2d 1241 (1971).

${ }^{24} 334$ F.Supp. 870 (D.Minn. 1971). It is important to note that the Van Dusartz opinion involved a summary judgment motion ruling and not a decision on the full merits.

${ }^{25}$ If filed today, federal statute would preclude Rodriguez from a three-judge federal district court panel. See 42 U.S.C. $\S 2284($ a) (limiting three-judge federal panels to apportionment cases as well as any other case required by Congress).

${ }^{26}$ Rodriguez v. San Antonio Indep. Sch. Dist., 337 F.Supp. 280, 282-23 (W.D. Tex. 1972), rev'd, 411 U.S. 1 (1973).

${ }^{27}$ For a more formal and theoretical version of this argument, see Charles Tiebout, A Pure Theory of Local Expenditures, 64 J. Pol. Econ. 416 (1956).

${ }^{28}$ Rodriguez, 337 F.Supp. at 284 ("Hence, the present system does not serve to promote one of the very interests which defendants [State of Texas] assert.”).

${ }^{29}$ Id. at 285. The court also identified various aspects of the Texas Constitution and Texas Education Code that contributed to plaintiffs' harm.

${ }^{30} I d$. at 284 ("Not only are defendants unable to demonstrate compelling state interests for their classifications based upon wealth, they fail even to establish a reasonable basis for these classification.”).

${ }^{31}$ Irons, supra note 2, at 286.

32 See, e.g., Henry M. Levin, Educational Vouchers: Effectiveness, Choice, and Costs, 17 J. Pol'y Analysis \& Mgmt. 373, 374 (1998) ("Because student achievement is considered to be a universal goal of schools, it has become the sine qua non for evaluating school reforms.”).

${ }^{33}$ For articles generally skeptical of a correlation between educational spending and educational opportunity, see Eric A. Hanushek et al., Making Schools Work: Improving Performance and Controlling Costs (1994); Clayton P. Gillette, Opting Out of Public Provision, 73 Den. U. L. Rev. 1185, 1213-14 (1996); Eric A. Hanushek, Money Might Matter Somewhere: A Response to Hedges, Laine, and Greenwald, 23 Educ. Researcher 5 (1994); Allan R. Odden \& Lawrence O. Picus, School Finance: A Policy Perspective 277-81 (1992); Eric A. Hanushek, When School Finance "Reform" May Not Be Good Policy, 28 Harv. J. on Legis. 423 (1991); Eric A. Hanushek, The Impact of Differential Expenditures on School Performance, 18 Educ. Researcher 45 (1989); Eric A. Hanushek, Throwing Money at Schools, 1 J. Pol'y Analysis \& Mgmt. 19 (1981). For articles generally supportive of a correlation between expenditures and educational opportunity, see Larry V. Hedges et al., Does Money Matter? A Meta-Analysis of Studies of the Effects of Differential School Inputs on Student Outcomes, 23 Educ. Researcher 5 (1994); Ronald F. Ferguson, Paying for Public Education: New Evidence on How and Why Money Matters, 28 Harv. J. on Legis. 293 (1991); Christopher F. Edley, Jr., Lawyers and Education Reform, 28 Harv. J. on Legis. 457 (1991). 
${ }^{34}$ See, e.g., James S. Coleman, et al. U.S. Dep’t of Health, Educ. \& Welfare, Equality of Educational Opportunity 304 (1966) (hereinafter "Coleman Report") (finding that "student body characteristics" account for an impressive percent of variance" in student achievement, and that "[c]hildren from a given family background, when put in schools of different social compositions, will achieve at quite different levels"). Scores of subsequent studies have confirmed Coleman's conclusion. For citations to the literature, see Richard D. Kahlenberg, All Together Now: Creating MiddleClass Schools Through Public School Choice 26-28, 86-69 (2001); James E. Ryan, Schools, Race, and Money, 109 Yale L.J. 249, 287 n.167 (1999).

35 James Coleman, one of the nation's leading and most prominent sociologists, taught at Johns Hopkins University and the University of Chicago. Much of his work profoundly influenced public policy, especially education policy.

${ }^{36}$ See Coleman Report, supra note 34, at 298-305.

${ }^{37}$ See id. at 21-22, 296-97, 312-16.

${ }^{38}$ See supra note 33 and accompanying text.

${ }^{39}$ See Gary Orfield \& Susan Eaton, Dismantling Desegregation: The Quiet Reversal of Brown v. Board of Education 53 (1996) (stating that the powerful influence of the socioeconomic status of peers on student achievement is "one of the most consistent findings in research on education”).

${ }^{40}$ James S. Coleman, Toward Open Schools, 9 Pub. Int. 20-21 (Fall 1967) (summarizing findings of Coleman Report). For discussion of the numerous studies confirming this point, see Kahlenberg, All Together Now, supra note 34, at 2628.

${ }^{41}$ See Richard D. Kahlenberg, Learning From James Coleman, 144 Pub. Int. 54 (2001). See also Chester E. Finn, Jr., Education That Works: Make the Schools Compete, 65 Harv. Bus. Rev. 64 (1987) (acknowledging that "disadvantaged children [tend] to learn more when they attend[] school with middle-class youngsters"); Interview by Ted Koppel with Jonathan Kozol, Nightline (ABC television broadcast Sep. 17, 1992), (stating that "money is not the only issue that determines inequality. A more important factor, I am convinced, is the makeup of the student enrollment, who is sitting next to you in class”), quoted in Kahlenberg, All Together Now, supra note 34, at 37.

42 Trine Tsouderos, Kids in City's Poor Schools Get Worse Scores, Tennessean, Dec. 27, 1998, at 2A (quoting James Guthrie).

${ }^{43}$ For a helpful summary of Professor Coleman's thirty-five years of research in the education policy area, see Kahlenberg, Learning, supra note 41.

${ }^{44}$ See James S. Coleman, Thomas Hoffer \& Sally Kilgore, High School Achievement: Public, Catholic, and Private Schools (1982).

45 Thomas C. Berg, Anti-Catholicism and Modern Church-State Relations, 33 Loy. U. Chi. L. Rev. 121, 165 (2001).

${ }^{46}$ Rodriguez, 337 F.Supp. at 285.

${ }^{47}$ Id. at 286.

${ }^{48}$ Rodriguez, 411 U.S. at 71 (Marshall, J., dissenting)(arguing that it is insufficient to remit school finance plaintiffs "to the vagaries of the political process which . . . has proved singularly unsuited to the task of providing a remedy for this discrimination"); J. Ely, Democracy and Distrust 84 (1980)("[E]ven the technically represented can find themselves functionally powerless ...."). See generally Note, Unfulfilled Promises: School Finance Remedies and State Courts 104 Harv. L. Rev. 1072 (1991) (arguing against judicial reliance on the legislative and executive branches in the school finance reform context in state courts).

49349 U.S. 294 (1955).

${ }^{50}$ See, e.g., Doug Rendleman, Brown II’s “All Deliberate Speed” at Fifty: A Golden Anniversary or a Mid-Life Crisis for the Constitutional Injunction as a School Desegregation Remedy?, 41 San Diego L. Rev. 1575 (2004).

${ }^{51}$ Griffin v. County Sch. Bd., 377 U.S. 218, 229 (1964).

52 See, e.g., Michael Heise, Preliminary Thoughts on the Virtues of Passive Dialogue, 34 Akron L. Rev. 73 (2000)(discussing New Jersey’s four-decade school finance saga).

${ }^{53}$ Paul Gewitz, a law professor at Yale, is an expert in federal courts and jurisdiction.

${ }^{54}$ Paul Gewirtz, Remedies and Resistance, 92 Yale L.J. 585, 674 (1983).

${ }^{55}$ Irons, supra note 2, at 288. 
56 Justice Powell was appointed to the Richmond (Virginia) School Board in 1950, and served as the Board Chair from 1952-60. See John C. Jeffries, Jr., Justice Lewis F. Powell, Jr. 124, 131-82 (1994).

${ }^{57}$ Rodriguez, 411 U.S. at 18-25.

${ }^{58} \mathrm{Id}$. at 29.

${ }^{59}$ Id. at 35 ("Education, of course, is not among the rights afforded explicit protection under our Federal Constitution. Nor do we find any basis for saying it is implicitly so protected.").

60347 U.S. 483 (1954).

${ }^{61} I d$. at 36.

${ }^{62}$ Id. at 37.

${ }^{63}$ Robinson v. Cahill (Robinson I), 303 A.2d 273, 291-92 (N.J. 1973); N.J. Const. art. VIII, § 4, par. 1.

${ }^{64}$ Rodriguez, 411 U.S. at 67 (White, J., dissenting).

${ }^{65} \mathrm{Id}$. at 70 .

${ }^{66} I d$. at 112 (Marshall, J. dissenting).

${ }^{67}$ Id. at 83-84.

${ }^{68} \mathrm{Id}$. at 84 ("Discrimination in the opportunity to learn that is afforded a child must be our standard.").

${ }^{69}$ The Court noted:

[E]ducation is perhaps the most important function of state and local governments. Compulsory school attendance laws and the great expenditures for education both demonstrate our recognition of the importance education to our democratic society. It is required in the performance of our most basic public responsibilities, even service in the armed forces. It is the very foundation of good citizenship. Today, it is a principal instrument in awakening the child to cultural values, in preparing him for later professional training, and in helping him to adjust normally to his environment. In these days, it is doubtful that any child may reasonably be expected to succeed in life if he is denied the opportunity of an education. Such an opportunity, where the state has undertaken to provide it, is a right which must be made available to all on equal terms.

Brown v. Bd. of Educ. (Brown I), 347 U.S. 483, 493 (1954).

${ }^{70}$ Rodriguez, 411 U.S. at 36.

${ }^{71}$ Id. at 35.

72457 U.S. 202 (1982).

${ }^{73}$ Id. at 221.

${ }^{74}$ Rodriguez, 411 U.S. at 35-36.

75383 U.S. 663 (1966).

${ }^{76}$ Id. at 667 (quoting Reynolds v. Sims, 377 U.S. 533, 561-62 (1964)).

${ }^{77}$ See id.

${ }^{78}$ See, e.g., Dandridge v. Williams, 397 U.S. 471 (1970); Lindsey v. Normet, 405 U.S. 56 (1972).

${ }^{79}$ Rodriguez, 411 U.S. at 36.

${ }^{80}$ Id. at 37. For a discussion, see e.g., Susan H. Bitensky, Theoretical Foundations for a Right to Education Under the U.S. Constitution: A Beginning to the End of the National Education Crisis, 86 Nw. U. L. Rev. 550 (1992); Brooke Wilkins, Should Public Education be a Federal Fundamental Right?, 2005 BYU Educ. \& L.J. 261 (2005).

${ }^{81} 413$ U.S. 189 (1973).

82402 U.S. 1 (1971).

${ }^{83}$ Id. at 26. 
${ }^{84}$ See Brief for the Appellees at 20-22, San Antonio Indep. Sch. Dist. v. Rodriguez, 411 U.S. 1 (1973) (No. 71-1332). While the approach in Rodriguez failed, the approach has been refined since then and adopted by leading school finance advocacy groups with mixed success. See, e.g., Campaign for Fiscal Equity v. New York, 801 N.E.2d 326, 333-40 (N.Y. 2003) (construing adequate education in terms of both traditional inputs and outputs).

${ }^{85}$ Professor Goodwin Liu teaches law at the University of California, Berkeley.

${ }^{86}$ Liu, supra note 22.

${ }^{87}$ Rodriguez, 337 F.Supp. at 285.

${ }^{88}$ Rodriguez, 411 U.S. at 43.

${ }^{89}$ See, e.g., John Dayton, Correlating Expenditures and Educational Opportunity in School Funding Litigation: The Judicial Perspective, 19 J. Educ. Fin. 167, 178 (1993) (describing state court responses to an asserted positive correlation between educational funding and opportunity).

${ }^{90}$ For a fuller treatment of this point, see Michael Heise, Schoolhouses, Courthouses and Statehouses: Educational Finance, Constitutional Structure, and the Separation of Powers Doctrine, 33 Land \& Water L. Rev. 281, 291-93 (1998).

${ }^{91}$ For a discussion, see, e.g., Rachel F. Moran, Brown’s Legacy: The Evolution of Education Equity, 66 U. Pitt. L. Rev. 155, 157 (2004); Michael Heise, Equal Educational Opportunity By the Numbers: The Warren Court's Empirical Legacy, 59 Wash. \& Lee L. Rev. 1309, 1324-25 (2002); Ryan, Schools, supra note 34, at 259-60.

92 See generally Sheff v. O’Neill, 678 A.2d 1267 (Conn. 1996) (demonstrating plaintiffs' decision to combine racial and poverty issues in a lawsuit against the state of Connecticut).

${ }^{93}$ See, e.g., Michael Rebell, Adequacy Litigations: A New Path to Equity, in Bringing Equity Back: Research for a New Era in American Education Policy 291, 192 (Janice Petrovich \& Amy Stuart Wells eds., 2005).

${ }^{94}$ For a discussion of how the equal education opportunity doctrine has evolved over time, see Michael Heise, Litigated Learning and the Limits of Law, 57 Vand. L. Rev. 2417 (2004).

${ }^{95}$ Professor James Ryan, a leading education law scholar, teaches law at the University of Virginia.

${ }^{96}$ Ryan, Schools, supra note 34, at 259.

${ }^{97}$ See, e.g., James E. Ryan, The Influence of Race on School Finance Reform, 98 Mich. L. Rev. 432 (1999).

${ }^{98} 678$ A.2d 1267 (Conn. 1996). See also supra note 92.

${ }^{99}$ Liu, supra note 22, at 105.

100418 U.S. 717 (1974).

${ }^{101}$ Milliken v. Bradley, 418 U.S. 717, 741-42 (1974) (citing Wright v. Council of Emporia, 407 U.S. 451, 469 (1972)).

${ }^{102}$ Id. at 742 (citing Rodriguez, 411 U.S. at 50).

${ }^{103}$ Mary Frase Williams, American Education and Federalism, in Government in the Classroom: Dollars and Power in Education 1 (Mary Frase Williams ed., 1978).

${ }^{104}$ Hawaii Department of Education, About Us, at http://doe.k12.hi.us/about/index.htm (last visited June 1, 2006) (noting Hawaii has “a single, statewide [school] district with 285 schools”).

105 See Rodriguez, 411 U.S. at 42-43.

${ }^{106}$ See, e.g., Brown v. Board of Education, 347 U.S. 483, 493 (1954) (noting education's importance to state and local governments).

107 See generally Denis P. Doyle \& Chester E. Finn, Jr., American Schools and the Future of Local Control, 77 Pub. Int. 77 (1984) (noting the diminution of local control over school policy over time).

${ }^{108}$ For a discussion of the federalism consequences in education policymaking authority shifts among local, state, and federal governments, see generally Michael Heise, The Political Economy of Education Federalism, 56 Emory L.J. 125 (2006).

${ }^{109}$ See Nat'l Comm'n on Excellence in Educ., A Nation at Risk: The Imperative for Educational Excellence (1983). See also Karen MacPherson, A Nation Still at Educational Risk: Two Decades Later Reports Still Focusing on the Mediocrity of U.S. Education, Pittsburgh Post-Gazette, Aug. 31, 2003, at A11 (discussing A Nation At Risk report). 
${ }^{110}$ MacPherson, supra note 109.

111 See R. Craig Wood \& Bruce D. Baker, An Examination and Analysis of the Equity And Adequacy Concepts of Constitutional Challenges to State Education Finance Distribution Formulas, 27 U. Ark. Little Rock L. Rev. 125, 15860 (2004).

112 Pub. L. No. 107-110, 115 Stat. 1425 (codified in scattered sections of 20 U.S.C.).

11320 U.S.C. § 6311(b)(3)(C)(vii) (Supp. II 2002).

${ }^{114}$ Id. at $\S 6311(\mathrm{~h})$.

${ }^{115}$ Id. at $\S 6311(\mathrm{~b})(1)$.

${ }^{116} I d$. at $\S$ 6311(b)(2). Although under NCLB states are not required to submit their standards to the Secretary of Education for review, states must submit plans that demonstrate a commitment to challenging academic standards. See id. at $\S 6311(\mathrm{~b})(1)(\mathrm{A})$.

${ }^{117}$ Id. at $\S$ 6316(b)(5), (8).

${ }^{118}$ Rodriguez, 411 U.S. at 58.

${ }^{119}$ Id. at 59.

${ }^{120} \mathrm{Id}$.

${ }^{121}$ Id. at $49-53$.

${ }^{122}$ Id. at 58 n.111.

${ }^{123}$ Id. at $57-58$.

${ }^{124}$ Id. at 41.

${ }^{125} \mathrm{Id}$. at 56-57.

${ }^{126} \mathrm{Id}$. at $58 \mathrm{n} .11$ (noting that approximately \$2.4 billion of additional new tax funds would be needed to bring Texas' lower-spending districts up to its highest spending counterparts).

${ }^{127}$ Id. at 56.

${ }^{128}$ Id. at 58.

${ }^{129}$ See id. at 58 ("The need is apparent for reform in tax systems which may well have relied too long and too heavily on the local property tax.”).

${ }^{130}$ See id. at 58-59.

${ }^{131}$ See id. at 59.

${ }^{132}$ Arthur E. Wise, Is Denial of Equal Educational Opportunity Constitutional?, 13 Admin. Notebook 1 (1965).

133 Arthur E. Wise, The Constitution and Equality: Wealth, Geography, and Educational Opportunity, (1968) (unpublished Ph.D. dissertation, University of Chicago) (on file with the University of Chicago).

${ }^{134}$ Phillip Kurland, Equal Educational Opportunity: The Limits of Constitutional Jurisprudence Undefined, 35 U. Chi. L. Rev. 583 (1968).

${ }^{135}$ Arthur Wise, Rich Schools, Poor Schools: The Promise of Equal Educational Opportunity (1968). In fairness, it is important to recognize that while Wise was researching and writing, the general issue was emerging among scholars. See, e.g., Harold W. Horwitz, Unseparate But Unequal: The Emerging Fourteenth Amendment Issue in Public School Education, 13 U.C.L.A. L. Rev. 1147 (1966).

${ }^{136}$ Wise, Denial, supra note 132, at 3-4.

137 The other pillar-undeveloped in Wise's 1965 essay-was education as a fundamental right under the U.S. Constitution.

138 Note, A Statistical Analysis of the School Finance Decisions: On Winning Battles and Losing Wars, 81 Yale L.J. 1303 (1972).

${ }^{139}$ Rodriguez, 337 F.Supp. at 282. 
${ }^{140}$ Note, Wars, supra note 138, at 1326, 1330 n.114.

${ }^{141}$ Id. at 1327.

${ }^{142}$ Id. at 1328.

${ }^{143}$ Id.

${ }^{144}$ Id. at 1327.

${ }^{145}$ Rodriguez, 411 U.S. at 23.

${ }^{146}$ Rodriguez, 411 U.S. at 23 (concluding there was no reason to assume that poor families in Texas cluster in poor spending school districts).

147 The school finance saga in Texas has been a multi-year drama. For a fuller description see, e.g., J. Steven Farr \& Mark Trachtenberg, The Edgewood Drama: An Epic Quest for Education Equity, 17 Yale L. \& Pol'y Rev. 607 (1999).

${ }^{148}$ Mark G. Yudof, School Finance Reform in Texas: The Edgewood Saga, 28 Harv. J. on Legis. 499, 505 (1991).

149 Tex. Const. art. I, § 3.

150 Tex. Const. art. VII, § 1 .

${ }^{151}$ Edgewood Indep. Sch. Dist. v. Kirby (Edgewood I), 777 S.W.2d 391, 399 (Tex. 1989).

152 Act of May 28, 1993, ch. 347, 1993 Tex. Gen. Laws 1479. Now codified in title 2, subtitle 1 of the Texas Education Code. Tex. Educ. Code Ann. Title 2.

153 For a discussion see, e.g., Maurice Dyson, The Death of Robin Hood?: Proposals for Overhauling Public School Finance, 11 Geo. J. on Poverty L. and Pol'y 1, 11-12, 51 (2004).

${ }^{154}$ Edgewood Indep. Sch. Dist. v. Kirby (Edgewood IV), 917 S.W.2d 717 (Tex. 1995).

155 Tex. Const. art. VIII, § 1-e.

${ }^{156}$ Neeley v. West-Orange Cove Consol. Indep. Sch. Dist., 176 S.W.3d 746, 754 (2005)(noting that the Texas Supreme Court warned about this prospect ten years earlier), rehearing denied (Dec. 16, 2005).

${ }^{157} I d$. (concluding that the local ad valorem taxes have become a de facto state property tax in violation of the Texas Constitution, art. VIII, § 1-e).

158 The state had until June 1, 2006, to respond to the court's concerns before injunctive relief becomes effective. Id. at 799. After three special legislative sessions, Texas lawmakers passed tax legislation that provided additional resources for Texas schools. The plaintiffs agreed only that the special legislative activity provided fiscal "breathing room" for the 2006-07 school year. As a consequence, both parties to the litigation agreed to a motion that confirmed the dissolution of the court's pending injunction. The district court judge John Dietz granted the motion on May 26, 2006.

${ }^{159}$ Id. at 754 (concluding that the Texas school finance system does not violate the "efficient system of public free schools” requirement in the Texas Constitution, art. VII, § 1).

${ }^{160}$ Id. at 751.

${ }^{161}$ Id. at 788.

162 See, e.g., Ex Parte James, 836 So.2d 813 (Ala. 2002); State of Ohio v. Lewis, 789 N.E.2d 195 (Ohio 2003).

${ }^{163}$ See, e.g., Alexandra Greif, Politics, Practicalities, and Priorities: New Jersey's Experience Implementing the Abbott V Mandate, 22 Yale L. \& Pol'y Rev. 615, 68-52 (2004).

${ }^{164}$ Opinion of the Justices, 624 So.2d 107 (Ala. 1993).

${ }^{165}$ Id. at 165-66 (noting the essential parts of a "liberal system of public schools”).

${ }^{166}$ Opinion of the Justices, 624 So.2d 107 (Ala. 1993).

${ }^{167}$ State of Ohio v. Lewis, 789 N.E.2d 195 (Ohio 2003).

${ }^{168} 615$ N.E.2d 516 (Mass. 1993).

${ }^{169}$ Mass. Ann. Laws ch. 69 (2002).

${ }^{170}$ Hancock v. Commissioner of Educ., 822 N.E.2d 1134 (2005). 
${ }^{171}$ Id. at 1137-46 (summarizing school finance litigation in Massachusetts).

172 Jan J. Russell, The Equity Myth, Tex. Monthly, Sep. 2005, at 154.

${ }^{173} I d$.

${ }^{174}$ Howard Gardner teaches at Harvard University’s Graduate School of Education.

${ }^{175}$ Howard Gardner, Paroxysms of Choice, N.Y. Rev. of Books, Oct. 19, 2000, at 44, 49.

${ }^{176}$ For current publicly available district-level data from the U.S. Department of Education, see National Center for Education Statistics, available at http://nces.ed.gov/ccd/districtsearch/.

${ }^{177} I d$.

${ }^{178} I d$.

${ }^{179}$ William J. Brennan, Jr., State Constitutions and the Protection of Individual Rights, 90 Harv. L. Rev. 489 (1977). 